УдК 94(497)"1914":930(497.1)"1918/1941"

329.73:929 Принцип Г.

DOI https://doi.org/10.31212/tokovi.2021.1.duj.13-40

Оригинални научни рад

Примљен: 17. 6.2020.

Прихваћен: 1. 10. 2020.

Sonja DUJMOVIĆ

Institut za historiju Univerziteta u Sarajevu

sonja.dujmovic@iis.unsa.ba

\title{
Kako je nestala revolucija - slučaj Gavrila Principa*
}

\begin{abstract}
APSTRAKT: Rad je pokušaj davanja odgovora na pitanje kako je došlo do toga da je u savremenim raspravama nestao revolucionarni sadržaj čina atentata. Razmatra se i način na koji je pojedinačni čin, odnosno njegov nosilac Gavrilo Princip postao dijelom kolektivnog sjećanja, sveden u granice vjersko-nacionalnog kolektiviteta i kako je iz tog svedenog determinisanja poslana redefinisana i redukovana poruka o njegovom identitetu.

KLJUČNE RIJEČI: Gavrilo Princip, atentat, revolucija, osuda, svečana sahrana, neutralizacija, religijsko-nacionalna konstrukcija, promijenjeni identitet, interpretacije, politička instrumentalizacija
\end{abstract}

Zadaća istoriografije sastoji se u nastojanju da dopunjuje znanja o prošlosti, da je učini razumljivijom i bližom savremenicima, ne bi li sa boljim razumijevanjem gradili sadašnjost, pa i budućnost, pri tome sa potpunom sviješću da taj posao nikada u potpunosti nije ispunjen i dovršen. Među svom tom silnom prošlošću, koja je često opterećujuća, procesima, događajima i ličnostima, postoje ipak one žižne tačke koje izazivački svijetle i koje su intrigantne u toj mjeri da im se gotovo svaka generacija istoričara nanovo vraća i preispituje stečena znanja o njima. Jedna od njih je i ona koja se ne može obuhvatiti jednim terminom, prelomni događaj koji

Osnovne konture rada prezentovane na Okruglom stolu Prvi svjetski rat. Globalna historija i kulturne konzekvence, Filozofski fakultet Univerziteta u Sarajevu, 11. novembar 2018. godine. 
nadilazi sve učesnike u svojoj složenosti, a obilježen je junom 1914. godine i pucnjevima Gavrila Principa na nadvojvodu Franca Ferdinanda, prestolonasljednika austrougarskog trona, na jednoj od sarajevskih ulica tik do Miljacke, čiji su se odjeci mjesec dana u toj mjeri proširili iz ovog bosanskog grada put Beča, Beograda, ${ }^{1}$ pa potom prestolnicama Evrope i drugih kontinenata, označavajući ga povodom za neslućenu ljudsku kataklizmu zvanu Prvi svjetski rat, pri čemu je Sarajevo ostalo trajna asocijacija na njegov početak, bez obzira na pokušaje da se „nanesena ljaga opere“.2

U tim danima i događajima, čin glavnog aktera, po tadašnjim zakonima maloljetnog Gavrila Principa, prestaje da bude samo njegov, postaje tačka interesa i po službenoj dužnosti policijskih činovnika, prisutih građana Sarajeva i brojnih vladinih službenika, političara, ministara, okrunjenih glava i vojnih glava širom svijeta, miliona do tada nezainteresovanih ljudi koji su zagazili u rat, da bi u nizu od stotinu godina potom bivao predmetom razmišljanja radoznalih osoba i proučavanja zainteresovanih istraživača. Ova posvećenost i prilježnost onih koji su se pozvali da riješe kompleksnu enigmnu s razlogom stvorenu oko Sarajevskog atentata, nevjerovatan broj pisanih tragova i tekstova koji ga se dotiču, ${ }^{3}$ realnih i imaginarnih predstava, proisteklih i stvorenih nenamjerno ili sa zacrtanim interesima, omogućena je i nesrazmjerno malim brojem iskaza

10 odjecima u susjedstvu vidjeti: Горан Васин, „Пречанска политика и сарајевски атентат“, Ћоровићеви сусрети 2013. године. Међународни научни скуп историчара Сарајевски атентат 1914, ур. Војислав Максимовић, Драга Мастиловић, (Гацко: СПКД „Просвјета“, Општински одбор Гацко, 2014), 164-176; Будимир Алексић, „Одјек сарајевског атентата у Краљевини Црној Гори“, Ћоровићеви сусрети 2013. године, 233-246.

2 Iz proglasa Gradskog načelstva sugrađanima, u kojem se, između ostalog, kaže: „Sa najvećim gnušanjem osudjujemo počinjeni pakleni čin, a unesrećeni smo osobito, što se on dogodio u Sarajevu, pa pozivamo cjelokupno sarajevsko gragjanstvo, koje se još uvijek vjernim i lojalnim pokazalo, da ovakove i slične izmete ljudskoga roda i z s v oje sr ed in e is trije bi, da u buduće predusretne tako sramotnim zlodjelima. - Sveta će dužnost biti gragjanstva sarajevskog sve učiniti, da se ova danas našem Sarajevu nanesena ljaga opere, a trebat će složo raditi, d a s e p r o či st i s a raj e v s k o st an o v n iš t v o, koje je bilo i jeste vazda lojalno i nepokolebivo odano Prejasnoj Kruni i slavnom Habsburškom domu." „Gradsko načelništvo kralju i građanima“, Hrvatski dnevnik, br. 143, Sarajevo, 29. lipnja 1914, 2.

3 U jednoj od obimnih studija koja se bavi međunarodnom interesnom političkom i diplomatskom scenom, mladobosanci se karakterišu kao teroristički pokret, koji se više bojao reformističke i umjerene politike koja bi dovela do trijalističkog ustrojstva Monarhije i time onemogućila pijemontsku ulogu Srbije, a Gavrilo Princip se vidi modeliran u svijetu iredentističkih mreža i pokreta. Christopher Clark, The Sleepwalkers. How Europe Went to War in 1914, (London: Alan Lane an imprint of Penguin Books, 2012), 49, 52. 
datih od ćutljivog i ćudljivog Principa. ${ }^{4}$ Time je omogućeno konstruisanje brojnih tumačenja, uspostavljanje poveznica i izvođenje zaključaka. Svim tim narativima, bez obzira na uložene napore, zajednička je nemogućnost sveobuhvatnog pogleda, slijedio je uvijek nužno jedan retsriktivni, selektivni pristup. Ipak, svaki od njih s vremenom je dopunjavao složeni mozaik, taj proces je još u toku, ali nekim čudom ne uspjeva da naruši rađanje novih zapitanosti.

Jedna od njih je i sljedeća, a koja bi se mogla definisati pitanjem kako je došlo i do toga da se upitnom postavlja revolucionarnost samog čina, taj nezustavljivi i u biti samoubilački gest želje za promjenom socijalnih odnosa, ne samo motivisan društvenom pozicijom članova mladobosanskog omladinskog kruga nego cjelokupnog bosanskohercegovačkog, većinski seljačkog svijeta i nadom da će taj čin izmijeniti njegov državni okvir, osvješten kao autoritarni, silom nametnuti kolonijalni pritisak. Čime je omogućeno, uz činjenicu da je Princip pripadnik jednog, srpskog naroda, da se mnoge rasprave zasnivaju na sumnji u njegove u to vrijeme savremene, mladošću, idejama i žarom potaknute prevratničke namjere, za koje je žrtvovao, koliko se zna, bez žala i svoj život. Dakle, kako, gdje i zbog čega je nesta(ja)o revolucionarni sadržaj čina atentata.

Ideja za ovo razmišljanje potaknuta je periodikom i dokumentima, odnosno stalno prisutnom riječju kosti u nazivima lokalnih odbora koje su formirali preživjeli ratnici, veterani ili građani nakon Prvog svjetskog rata okupljeni oko ideje prenošenja posmrtnih ostataka (ovdje, takođe, uz svu svjesnost upotrebe ovovremenog eufemizma) prvenstveno palih vojnika, ali i drugog stradalog stanovništva, koji su prekrajanjem granica ostali na mnogim bojištima, u kosturnicama i na grobljima van matične zemlje. Široko rasprostranjena praksa organizovanih akcija pronalaženja, skupljanja kostiju u zajedničke grobnice, prenosa njihovih zemnih ostataka u domovinu, sve u cilju manifestacionog sahranjivanja, javnih posvećivanja i komemoracija i u svrhu propagandnih poziva na „vječno sjećanje" na njihove žrve, njihove specijalne i posvećene smrti, na njihov heroizam služila je osnaživanju ideje kolektivnih dobiti sa novouspostavljenom državom. To su bile ustaljene ideološke matrice upotrebe smrti/ kosti, te svjesno date žrtve za konstruisanje sjećanja kolektiva koja su tumačile nove političke i religiozne elite.

$4 \quad 0$ tome vidjeti u jednoj od najprilježnijih i najpotpunijih zbirki sjećanja i dokumenata o Principu i mladobosancima: Милош Ковић, Гаврило Принцип. Документи и сећања, (Нови Сад: Прометеј, Београд: РТВС), 2014. 
Ove akcije dakle nisu bile nikakav ekskluzivitet Kraljevine Srba, Hrvata i Slovenaca, već su sastavni dio poratnog evropskog trenda upokojavanja ratnika, i ne samo njega, nego sastavni dio svih ratnih završnica i procesa pomirenja koji ih prate, pa s tim u vezi ni prenos zemnih ostataka Gavrila Principa, preminulog u Terezinu 28. aprila 1918. godine, koji nije dočekao željenu slobodu, nije bio van toga procesa. ${ }^{5}$ Ipak, njegova „slava“ atentatora i političkog revolucionarnog aktera dodatni je razlog za zainteresovanost zbog načina na koji je pojedinačni čin, odnosno njegov nosilac, postao dijelom kolektivnog sjećanja, sveden u granice vjersko-nacionalnog kolektiviteta i kako je iz tog svedenog determinisanja poslana redefinisana i za vlasti poželjna poruka, putem prenošenja zemnih ostataka i ponovnog sahranjivanja u kolektivnu grobnicu. Razlaganje ovog procesa je možda i put pronalaženja odgovora na prethodno postavljena istraživačka pitanja.

Neupitna težina simbolike kosti i ostalih dijelova skeleta i njegova vezanost za magijske i religijske rituale, kao i za stalnu prisutnost sakralne umjetnosti u ljudskoj vizuri, potencirala je tokom vijekova strahopoštovanje vjernih, podsjećajući ih na ljudsku prolaznost, ali istovremeno noseći i značenje jezgre besmrtnosti, neuništivog dijela ljudskog duha. To simboličko utjelotvorenje besmrtnosti, koje nadrasta sve i sa tim vezano strahopoštovanje kostiju navodi na pitanje da li je moguće, opravdano i svrsishodno, boriti se protiv tog značenja, postoji li nešto toliko snažno, sveto i kadro da se uhvati u koštac sa veličanstvenom snagom besmrtnosti.

Odgovor je da takvo šta ne postoji, pa slijedeći tu misao - to ne može biti niti ideja revolucije, proizašla iz naslaga političkih doktrina koje je nosila onovremena mladost Evrope a na tragu ideja o tiranoubistvu kao moralnoj dužnosti i rješenju za socijalno i političko ugnjetavanje, razvijenih anarhističkih učenja, macinijevskog poziva omladini, te sa druge strane prilično upitne naslonjenosti na slobodarsku tradiciju vlastitog naroda, ali i što je značajnije, konkretno suočena sa ustanovljenom rigidnom praksom Monarhije u onemogućavanju omladinskih udruženja. U otporu tolikim pritiscima omladina prve dekade 20. stoljeća, zanesena i nadahnuta i užarenim govorima svojih starijih prijatelja, napajanih idejama na univerzitetima Monarhije, tražila je vlastiti put. Sam Princip, po svojoj misaonoj vodilji, spremno je dao život za smrt, odnosno besmrtnost. Dalje mi-

5 Sličnim problemom, nakon II svjetskog rata, bavi se i studija: Nikolai Vukov, „Collective Interments: Ossuaries and Brotherly Mounds in Bulgaria, 1944-1989“, Dying and Death in 18th-21st Century Europe, eds Marius Rotar, Adriana Teodorescu, (Cambridge Scholars Publishing, 2011), 129-149. 
saone akrobacije vode konstataciji da je bolje biti mrtav tj. besmrtan nego živ, ${ }^{6}$ pa makar i revolucionar, naročito ukoliko se notira da je Princip ostavio na zidovima svoje mistične tamnice u Terezinu, u kojoj je nekad boravio i jedan od glavnih pokretača pobune protiv Austrougarske monarhije Sarajlija Hadži Lojo, ${ }^{7}$ stihove sličnog smisla. ${ }^{8}$

Gavrilo Princip je svojim dugo željenim i sa drugovima planiranim činom isprovocirao odgovore svih socijalnih grupa bosanskohercegovačkog društva, pa se pokazalo da su ga podržale samo takozvane niže klase, pjesnici, intelektualci i omladina, ${ }^{9}$ dok su njegovu metodu obračuna sa Austrougarskom monarhijom, oličenom u prestolonasljedniku, odmah osudili uglednici i crkveni velikodostojnici. Po pripadnosti istoj, srpskoj nacionalnoj zajednici, poslije atentata, prvih julskih dana 1914. godine, srpski društveni vrhovi, virilni članovi i poslanici sabora, među kojima

$6 \quad$ Naslovni tekst demokratskog Naroda nakon sahrane Principa i drugova glasio je „Kroz smrt u život“. Glas naroda, br. 276, (Sarajevo), 7. jula 1920, 1.

7 U tekstu podnaslova „Objašnjen misterij - Ruže“ navodi se da se događaju „zadnjeg vremena vrlo čudne stvari“ i da „ima već dulje vremena kako iz zidova izbijaju crvene mrlje poput krvi, pa narod u Terezienstadte vjeruje da je to krv pokojnog Principa. Međutim, prema izvidima utvrđeno je da je ovo ćelija koja je nekad omalovana crvenim ružama i da se boja od tih ruža pokazuje. Vjeruje se da su te crvene ruže malovane u ćeliji kad je u njoj bio Hadži Lojo, jer je on u ovoj istoj ćelili, u kojoj je ležao i umro pok. Princip, proveo 5 godina. Međutim, interesantno je to da je dosad već nekoliko puta zid okrečen i bojen, ali da to ne pomaže i crvene mrlje stalno izbijaju na površinu.“ „U ćeliji Principa i Hadži Loje“, Večernja pošta, br. 2347, (Sarajevo), 20. aprila $1929,1$.

8 „Tromo se vreme vuče I ničeg novog nema,

Danas sve ko juče

Sutra se isto sprema.

$(\ldots)$

Al' pravo je rekao pre

Žerajić soko sivi:

'Ko hoće da živi nek mre,

Ko hoće da mre nek živi!"“

Vladimir Dedijer, Sarajevo 1914, (Beograd: Prosveta, 1969), 557.

9 Znatan dio srednjoškolaca odmah po atentatu je bio privođen i ispitivan, što za njih nije bilo ništa novo, jer su hapšenja srednjoškolaca bila praksa iz 1912. godine zbog njihove podrške srpskoj vojsci tokom balkanskih ratova. „Manifestacije su se redovno pretvarale u demonstracije protiv Austro-Ugarske Monarhije i završavale sukobom sa policijom. Tada je policija hapsila koga god je stigla. Za kratko vremena znatan broj srednjoškolaca upoznao se sa policijskim zatvorom. To je postala neka vrsta legitimacije za nacionalnu borbenost. Bili smo se već navikli na kućne premetačine i hapšenja kao na svakodnevne pojave.“ Цветко Поповић, Сарајевски Видовдан 1914, Доживљаји и сећања, (Београд: Просвета, 1969), 22. 
sva četiri mitropolita, požurili su da se ograde od ovog „gnusnog čina“. ${ }^{10}$ Po prirodi stvari, sveštenstvo, profesionalni poveznici sa onostranim, bilo je rječitije, a mitropolit banjalučki Vasilije Popović je npr. na parastosu za nadvojvodu i njegovu suprugu, među pastvom, između ostalog, stigmatizujući Principa izrekao:

„Bezbožno i gnusno djelo bi demonski izvršeno i izvedeno, te nam svima (...) u našoj kući (...) pade od proklete ruke bezbožnog i razornim idejama zaraženog djeteta iz ove očajne zemlje naše. (...) Ovde nas, tužni zbore, pamet ostavlja, snaga nas izdaje, i to sasvim onako, kao što oca ili majku nesvjest snalazi kada iznenadno čuju, da je njihovo rođeno dijete učinio kakvo gnusno, sramno i odvratno djelo, radi koga ga i sami njegovi roditelji proklinju i osuđuju. Ali ne, to nije naše dijete, to nije naš rod, to je naš izrod, to je naš odrod. One bezbožne, pogubne i anarhističke misli, koje su u bezumnoj glavi toga djeteta bile i kružile, nije su to misli našega dobrog i pobožnog naroda."

Kako su stvari postale ozbiljnije i objavljen rat, sto uglednih Srba Sarajlija izjavilo je 31. jula 1914. lojalnost, preko svojih predstavnika, izražavajući spremnost da „za svoga uzvišegoga vladara, Njegov Prejasni Dom i našu domovinu" doprinesu sve žrtve. Njihovim primjerom su išli Srbi i u drugim bosanskohercegovačkim gradovima - Mostaru, Bihaću, Tuzli, Bu-

10 „Našim čitaocima“, Istina, br. 94, (Sarajevo), 21. jun/4. jul 1914, 1. - Ostali virilisti su kao članovi Srpske narodne stranke bili potpisnici rezolucije u kojoj između ostalog navode da je atentat „duboko ispunio naše osećaje zgražanjem protiv podmuklog zločina“: dr Milan Hadži-Ristić, dr Vladimir Andrić, dr Jovo Simić, dr Ljubo Simić, advokat Danilo Dimović, sveštenik Jakov A. Popović, dr Dimitrije Vasić, dr Milan Jojkić, sveštenik Jovo Simić, Vaso Vasiljević i Vukan Kuljanin. Istina, br. 97, 28. jun/11. jul 1914, 1.

11 Slično je govorio i mitropolit Ilarion Radonić na parastosu 21.juna/4.jula u tuzlanskoj srpsko-pravoslavnoj crkvi: „Da strašna, da užasna zločina, nad kojim se s prezirom zgražamo i koga najoštrije osuđujemo (...) zločinačka, niska nečovječna i bezbožna ruka dvojice propalih individua posegnu za pakleno oružje i opasnim, bogomrskim činom usmrti dva nevina bića, (...) a u srcima nas vjernih i odanih odjeknula je neugasivim bolom i preteškom tugom. Tu tugu, taj pregolemi bol pokreće istinska ljubav naša, koju su visoki pokojnici potpuno zaslužili“. „Govor mitropolita Ilariona Radonića na parastosu“, Istina, br. 97, 28. jun /11. jul 1914, 3.

$\mathrm{U}$ istom fonu se srpsko-pravoslavno sveštenstvo tokom rata osvrtalo na Principov čin. Na svečanom parastosu u srpsko-pravoslavnoj crkvi 28. juna 1917. uz prisustvo mitropolita Letice i više sveštnika, u govoru direktora reljevske bogoslovije Dimitrija Jakovića rečeno je i sljedeće: „No naša tuga za izgubljenim, naše zgražanje s podle povrede čuvenog nam gostoprimstva, naš bol zbog onoga, što se desilo i što se ne da popraviti, ne samo da nijesu popustili nego su se i tuga i bol i zgražanje skamenili, a cijelom svijetu svjedoče, da žalimo i da nećemo prežaliti krvavi dan 15/28. juna 1914.“ „Otkriće spomenika“, Sarajevski list, br. 164, 28. juna 1917, 3. 
gojnu, Travniku, Zenici, Banja Luci, Brčkom i dr. Na taj način su se ne samo ogradili od Principovog čina nego ga i ekskomunicirali iz svoje zajednice.

Nakon rata, šest godina kasnije, 1920. Princip je ponovo, ali sada višom silom, svojom smrću, natjerao sve i društvene, i socijalne i nacionalne zajednice, pa i pojedince u Bosni i Hercegovini da se ponovno izjasne o odnosu prema onome što je sada, mimo njegove volje, njegovo ime značilo. To se dogodilo povodom prenosa Principovih kostiju iz Češke, njegove sahrane i njegovih drugova.

U tom momentu, nakon smrti miliona širom ratišta što ih je Prvi svjetski rat donio, među ostalim, postavljalo se pitanje šta uraditi sa tijelima i idejama onih čiji su iskazi ostali zabilježeni u policijskim zapisnicima, njihovim izrečenim idejama, riječima koje su stigle i u stupce predratnih novina, onih koji su poštovali ona moralna načela koja kao najvišu vrednost nalažu potrebu za samožrtvovanjem za dobrobit kolektivnog, za što nije bio dovoljan masarikovski „sitni rad“ već je „za njeno buđenje bio potreban miris krvi",12 onih koji su bili ne samo revolucionarno raspoložene patriote, idealisti i nacionalisti, sa idejom rušenja sistema i klicom anarhije, ${ }^{13}$ koji su u ideji o ubistu vladara slijedili trend evropskih anarhističkih krugova i kao vrlo odlučni kritičari društva, socijalnih nepravdi, konzervativizma i primitivizma prkosili svim institucijama, koji su prijekim putem htjeli riješiti sve socijalne i nacionalne probleme svog naroda; mladobosancima, kojima sarajevski tragični gost nije bio jedina moguća meta i koji su „smerali da ubiju ne samo Franju Ferdinanda i poglavara Potjoreka, nego i prvog sveštenika i građanske prvake iz Sabora“. Šta sa Principom koji je za revolucionarne omladince bio „svetac u poređenju sa aktivnim ili pasivnim braniocima grubosti i nepravde, čak i ako njegov protest uništava i druge živote pored njegovog ${ }^{\text {“ }}{ }^{14} \mathrm{U}$ momentu kada nije trebalo

12 Dedijer, Sarajevo 1914, 43, 401.

13 „Najprije, ne treba zaboraviti da se, blago rečeno, Austro-Ugarska u Bosni nije naročito isticala svojim liberalno-demokrataskim načinom upravljanja. Štaviše, čini se da su kolonijalne crte austrougarske uprave samo dolijevale ulje na buntovničko raspoloženje mladobosanaca." Stijn Vervaet, Centar i periferija u Austro-Ugarskoj, (Zagreb-Sarajevo: Synopsis, 2013), 332 (fusnota 336).

14 „Sam Gavrilo Princip izrazio je tu zajedničku mržnju protiv sarajevske čaršije kada je uoči 28. juna 1914. godine rekao da bi svu čaršiju zapalio kad bi je mogao strpati u kutiju šibica. Istu misao izrazio je i Nedeljko Čabrinović, koji je u istrazi 28. juna priznao da se nosio mišlju da uđe u sabor i sa galerije baci jednu bombu među poslanike, jer je bio uveren da su oni podlaci i kukavice, koji ništa ne rade, a i kad nešto rade, ništa vredno ne stvaraju. Na istom saslušanju on je izjavio da su on i njegovi drugovi smerali da ubiju ne samo Franju Ferdinanda i poglavara Potjoreka, nego i srpskog mitropolita Leticu, kao i srpske građanske prvake Jeftanovića, Dimovića i Jojkića." Dedijer, Sarajevo 1914, 343, 283. 
potencirati odgovornost za početak rata, kada su novi problemi potresali novostvorena društva, a revolucionarni talasi još uvijek zapljuskivali radništvo, atentatori su bili mrtvi, ali isuviše živi, s obzirom na njihove ideje i na to da je ime Principa već uveliko postalo poznato širom svijeta.

To je bio trenutak u kojem je još odzvanjalo jednogodišnje pregovaranje na Pariškoj mirovnoj konferenciji (18. januar 1918 - 21. januar 1920), vođeno interesima velikih evropskih sila, momenat u kome su novinske stupce ispunjavale zloslutne vijesti o politici rukovodstva i prilikama u uspostavljenoj sovjetskoj socijalističkoj državi i pojačavale strah od "sovjetskog imperijalizma“, a istovremeno na domaćem tlu se osjećao narastajući uticaj socijaldemokratske partije, iskazan i rezultatima prvih izbora, što je sve uznemiravalo mlađahne, jednoipogodišnje vlasti. Njihovu tjeskobu izazvao je i održan, upravo uoči sahrane, 20-25. juna 1920. godine, Vukovarski kongres socijalističke partije (komunista), u čijim je redovima objelodanjen sukob između revolucionarlnog i reformističkog koncepta, već duboko prisutan i u redovima socijaldemokratskih snaga evropskih zemalja. Tome je prethodio proglas Zinovjeva, predsjednika izvršnog odbora Treće internacionale, u kome se pozivaju radne mase balkansko-podunavskih zemalja na proletersku revoluciju. Tim povodom list vladajuće radikalne stranke proziva bosanske socijaldemokrate i njihovog predstavnika Sretena Jakšića: „Bosanski komunisti treba da se čisto i jasno izraze: da li odobravaju ovaj program i taktiku svoga vođe? Ovdje ne može biti vrdanja. Naša javnost i cio narod treba tačno da zna ko je neprijatelj ove države i kome je cilj, da putem revolucije, i to ove prave gdje padaju glave i gdje se krv prolijeva, stvara diktaturu proletarijata i sovjetsku republiku. ${ }^{15}$ Nije zaboravljena ni njemačka revolucija i posljedično pojačana duboka socijalna previranja koja su potresala Evropu te 1920. godine, njene najveće prestolnice, izražene štrajkovima u Berlinu i brojnim njemačkim gradovima, te u Parizu takođe tog proljeća, a pod utiskom i primjerom boljševičke revolucije i izgradnje socijalističke države.

U Kraljevini su nezadovoljstvo značajno iskazali studenti Beogradskog univerziteta, a za njima željezničari generalim štrajkom. Glavni neprijatelj svih evropskih vlada postali su socijalnim prilikama nezadovoljni radnici sa revolucionarnim idejama i ciljevima, a sa kojima se obračunavalo vojskom i policijom. ${ }^{16}$ Sve što je „mirisalo“ na revoluciju bilo je nepoželjno i uzrokovalo rigoroznu reakciju i odmazdu vlasti, tako da je

15 „Наши бољшевици“, Српска ријеч, бр. 118, 17. јун 1920, 1.

16 Prijetnja radnicima policijom zabilježena je i aforizmom: „Proleteri svih zemalja raziđite se! Policija!“ Српска ријеч, бр. 36, 22. април/5. мај 1919, 1. 
Principovo prisustvo u revolucionarnoj konotaciji trebalo na svaki način izbjeći i ne dopustiti da sjećanje na njega postane ujedinjujuće za socijalno kolektivno tijelo i eventualni socijalni bunt. Mladobosanci nisu mogli biti revolucionarni heroji u vremenu kada je revolucija bila proskribovana. Zbog toga je u krugovima političke elite krenula „neutralizacija“, poništavanje revolucionarnog karaktera čina mnogo prije, na petogodišnjicu vješanja Principovih drugova u proljeće 1920, prilikom okupljanja nad grobovima trojice obješenih atentatora, čemu su prisustvovale najuglednije ličnosti politike i Srpske pravoslavne crkve. Dopis službenih novina kaže, promovišući tadašnji koncept nacionalne ideologije - jedinstvo „troimenog naroda“, da su obješena „tri čovjeka svog doba, tri tipa koji sačinjavaju svršetak jedne epohe. (...) Sa njihovim smrtima započelo je veliko spremanje za naš život." Pored ostvarenja „naše uzvišene nacionalne ideologije“, navodi se dalje, „te tri herojske glave koje su pale kao prvi krvavi obol za naše ujedinjenje (...) Te tri duše slile su se u jedno, da budu i poslje kao simbolični nagovještaj slijevanja naših triju narodnih duša u jednu. ${ }^{{ }^{17}}$ Simbolika ponovnog okupljanja heroja, njihov povratak u „ujedinjeno kolektivno tijelo", naglašena je govorom koji je slijedio nakon ovog uvodnog i kratkog. Detaljno razlaganje o sokolskom pokretu ${ }^{18}$ i povezivanje sa djelovanjem atentatora promovisalo je posljeratnu ideologiju jedinstva naroda i njegove ujedinjene snage.

Međutim, ovo okupljanje je istovremeno podsjetilo vlasti na opasnost koju radikalne ideje omladine mogu da imaju i izazvalo njenu brzu reakciju, te je nakon četiri dana zemaljska vlada izdala okružnicu kojom se uspostavlja, kao u vrijeme Monarhije, kontrolisanje „Đačkih udruženja

17 Ovom činu prisustvovao je predsjednik zemaljske vlade Atanasije Šola, šef likvidacije Narodne odbrane Stevo Žakula, povjerenik za socijalnu politiku Franjo Markić, komandant žandarmerije pukovnik P. Mitrović, narodni predstavnik dr Živko Nježić, potpukovnik Nikolić, direktor bogoslovije dr Tomo Popović sa nastavnicima i učenicima bogoslovije, inspektor Simo Stanivuković, „stara gđa Stoja mati našeg heroja D. Ilića, gđa Jovanka Čubrilović sa malešnom šćerkom, udovica i šćer našeg heroja Čubrilovića, Čubrilovića sestra gđa dr. Staka Bokonjić, predsjednica Zadruge Jugoslovenki gđa Jojkić, odbornice Dobrotvorne Zadruge Srpkinja i dr.“ „Godišnjica smrti heroja“, Narodno jedinstvo, br. 20, 3. februar 1920,1.

18 Sokolska organizacija je dio sokolskog pokreta formiranog u cilju moralnog i fizičkog vaspitanja naroda, „pobornik za narodne ideale, stvaralac boljega i snošljivijeg društavnog poretka te reformator teškog stanja u duhu savremenih principa na polju socijalnom, kulturnom i nacionalnom." A. Brozović, Soko Kraljevine Jugoslavije, (Beograd, 1930), 56. Nakon ujedinjenja nastojala je da kulturnim radom osnaži „misao poštovanja zajedničke nove države, misao bratske sloge i narodnog jedinstva“. Љубодраг Димић, Културна политика Краљевине Југославије 1918-1941, књ. I, (Београд: Стубови културе, 1996), 433. 
na srednjim i stručnim školama“, budući, kako se navodi, „Zemaljska Vlada misli, da srednjoškolsku mladež treba potpuno očuvati od političkih trzavica (...) te se ne može dopustiti, da faktori spolja djeluju na mladež odvraćajući je s jedne strane od glavnog zadatka, obrazovanja, za kojim ide, a s druge strane upotrebljujući je u svoje ciljeve, koji se uvijek nepodudaraju sa ciljevima škole.“19 U jednom od narednih brojeva se još kaže: „Do oslobođenja imala je naša politička javnost, naročito štampa nacionalnu dužnost, da omladinu održava u revolucionarnom ambijentu. Opasnost od kulta austrijskih careva i 'prejasne dinastije' (...) bila je tako velika (...) da su se morale staviti u pokret sve sile, da parališu ovaj kobni uticaj. (...) Ona predratna praksa, ukoliko je bila do oslobođenja potrebna, u toliko je danas poslije oslobođenja opasna. Mi danas imamo naše narodne škole, čiji djelokrug obuhvata (...) da stvori jedinstvenu generaciju, brisanjem preostalih štetnih elemenata u duši omladine. Dosljedno tome mora škola da energično odbije svaki uticaj izvana“. Stoga uvodničar zaključuje: „Smatramo kao potpuno opravdan i korisan akt društva srednjoškolskih profesora (...) da uskrati školskoj omladini javno kritikovanje rada škole i nastavnika",20 što je podrazumijevalo da je kritika društva krajnje nepoželjna, a da su brojni politički djelatnici i oportunistički profesori zaboravili na vlastito mladalačko iskustvo đačkih kružoka, ugrađeni u novi državni sistem svojim pozicijama. Napori vlasti da preduprijedi nepoželjnu djelatnost omladine nesumnjivo su je podsjećali na idejnu snagu Principove generacije i podsjećali je na otpor koji su nekadašnji njihovi vršnjaci pružili Monarhiji. Ipak, poznato je da intervencije vlasti nisu urodile plodom, a ni budni kritičari, ${ }^{21}$ budući da su upravo te generacije, a i one koje su za njima dolazile, bile one koje su na slobodarskim idejama iznijele buduću revoluciju.

Sa svoje strane Odbor srpske sokolske župe bosansko-hercegovačke je, na svojoj skupštini održanoj još 27 . aprila 1919, donio jedoglasni zaključak da Župa preuzme inicijativu kako bi „u najpodesnijem momen-

19 „Omladinska đačka udruženja“, Narodno jedinstvo, br. 24, 7. februar 1920, 4.

20 „Čuvajmo omladinu”, Narodno jedinstvo, br. 28, 13. februar, 1920, 1.

21 „Jer, dok je ranija generacija nesumnjivo napredna, revolucionarna, borbena i svjesna, ispovijedala vjeru i jedinstvo svih Jugoslovena, ova druga, povedena partijskim uticajima, stoji na stanovištu posebnih naroda, čak ne ni plemena - i za nju su čak i muslimani Bosne i Hercegovine poseban narod, - nije u tome ni za stopu odmakla od 'Obzora', 'Muslimanske svijesti' i drugih ostataka reakcije. Postoji dakle, u shvatanjima ovih dviju naprednih generacija omladine Bosne i Hercegovine očevidna kontradikcija. Po vremenu, moglo bi se očekivati da ova posljednja bude naprednija, ona, eto, otišla daleko unazad. Njoj, dakle, vrijeme nije išlo u prilog već na štetu.“ „Politički pregled“, Jugoslovenska pošta, br. 2653, (Sarajevo), 19. februar 1938, 3. 
tu prenele na dostojno mesto kosti trojice sokolskih heroja koji su sahranjeni u Sarajevu", što je i učinjeno. Odbor je potom obavijestio da su kosti „trojice heroja ekshumirane u Terezinu i spremenljene za prenos; za trojicu ostalih, koji su sahranjeni u Melersdorfu, nije se još ništa učinilo“.22 Stoga je Župa sazvala sve izaslanike kulturnih ustanova i druge viđenije ličnosti na sastanak u Oficirskom domu, ${ }^{23}$ te 8. februara 1920. oformila Odbor za prenos kostiju, koji će učiniti značajne pripreme „dostojne kostiju koje nećemo pustiti da leže u tuđoj zemlji, pa makar ona bila i prijateljska i bratska“ i učiniti sve „da im se zemni ostaci prenesu u rodnu grudu prostrane nove otadžbine“. Tom prilikom u diskusiji je naglašena „neophodna potreba jedne intenzivnije akcije oko prenosa kostiju s v i h atentatora koji su danas u Českoj, kao i postavljanje vidnog spomenika“. ${ }^{24}$ Njihovo prvo obraćanje desetak dana kasnije „braći Srbima, Hrvatima i Slovencima, te sestrama Srpkinjama, Hrvaticama i Slovenkama", da daju novčani prilog Odboru, donijelo je i dodatak imenu, koji je sada glasio Odbor za prenos kostiju vidovdanskih heroja, sa tada aktuelnim predsjednikom zemaljske vlade Atanasijem Šolom i članovima odbora koji su bili funkcioneri župe, svi „sokolski radnici i 'veleizdajnici', jer je najprirodnije da oni vode brigu o prenosu kostiju svojih drugova“.25 Mada je rečeno „da je prvenstvena dužnost svakog svesnog Srbina, Hrvata i Slovenca, koji znade tačno da oceni veličinu dela što su ga oni izveli“, kao i da je „funkcija odbora samo preparatorna, a biranju velikog svečanosnog odbora pristupće se docnije, pred sam prenos“, naglašeno je da Odbor „nije nipošto nametnut, nego da ima punovaljanu legitimaciju da poradi na ovom velikom i eminentno nacionalnom delu, punom pieteta i priznanja, s kojim političko uverenje pojedinaca nema apsolutno nikakve veze. Stvar je tako sveta i opšta, da je greh i pokušaj potezati je u kao naših partijskih zadevica. ${ }^{26}$

22 Ekshumaciju kostiju Neđe Kerovića, njegovog sina Mitra Kerovića, te Jakoba Milovića u melersdorfskoj tamnici uradili su „medicinar” Britvić i Čeh Lacer 21. maja 1920. godine. „Prenos kostiju sarajevskih atentatora”, Srpska riječ, br. 105, 1. juni 1920, $1-2$.

23 Sastankusu prisustvovali članovidruštava Prosvjeta, Pobratimstvo, Srpskatrgovačka omladina, Sokolsko društvo, Sloga, Zanatlijsko udruženje i Savez dobrovoljaca.

24 "Odbor za prenos kostiiju“, Narodno jedinstvo, br. 25, 9. februar 1920, 2.

25 Odbor za prenos kostiju vidovdanskih heroja: predsjednik Atanasije Šola, potpredsjednik Stevan Žakula, tajnik Miloš Đuran, blagajnik Spiro Soldo, odbornici: Simo Mirković, dr Vojislav Besarović, Vasilj Grđić, Jovo N. Popović, dr Vukašin Babunović, dr Bogdan Vidović. „Proglas Odbora za prenos kostiju vidovdanskih heroja“, Narodno jedinstvo, 37, 24. februar 1920, 2.

26 „Prenos kostiju naših heroja“, Narodno jedinstvo, br. 40, 27. 2. 1920, 3-4. - Budući da je u to vrijeme bilo puno štamparskih grešaka, vjerovatno je u posljednjoj rečenici trebalo da stoji: „potezati je kao u naših partijskih zadevica“. 
Ipak, ovim potezima - inicijativom, članstvom Odbora, održavanjem sjednica u Srpskom domu u Jelićevoj 28 i potporom srpskih društava - učinjeno je nekoliko prvih koraka da se Princip i drugovi uz podršku vlasti uvedu u jedno nacionalno, srpsko kolektivno tijelo, te ostave „u pričuvi“ Vidovdanskog panteona.

Od tada do dana sahrane u julu 1920. promijenio se predsjednik vlade (Atanasije Šola - Milan Srškić), dakle, umjesto demokrate ustoličio se radikal, koji nije po funkciji postao i predsjednik navedenog odbora. U međuvremenu je poželjnom proslavom obilježena 70-ta godina Tomaša Masarika, nositelja predratne ideje postupno prosvetiteljskog rada i etičkog odricanja od radikalizma, ali je istinski socijalni bunt, štrajk željezničarskih radnika, ugušen drakonskim mjerama vlasti, prozvan „političkim“. ${ }^{27}$ Da su dileme bile prisutne, vidi se i po tome što se gradskim vlastima čak u jednom momentu činilo poželjnim i uređenje mjesta atentata, računajući na radoznale turiste. ${ }^{28}$

Nakon obavijesti sredinom maja da prilozi Odboru ne stižu željenom brzinom, upozorava se da će ostati ,jedna neizbrisiva ljaga na celom našem društvu, ako radi nemarnosti i ravnodušnosti kosti ovih heroja ostanu i dalje razbacane u tuđini a često i na nedostojnim mestima“. Navodi se i da je postojeći odbor iz Hadžića, ${ }^{29}$ koji je već skupio 50.000 dinara priloga, likvidiran u korist ovoga u Sarajevu, ${ }^{30}$ da bi se ujedinili napori u korist akcije. Štampa je mjesec dana kasnije, sredinom juna, javila da su pripreme za prenos već gotovo završene zahvaljujući omladincima,

27 Uporište „protivštrajkaškoj politici“ nađeno je i u pismu Artura Hendersona, vođe engleske radničke partije, upućenom svom članstvu u kome izjavljuje „da njegova partija nije pristaša diktature kao načela u akciji (...) Prima tome i ne želimo uspostaviti nikakvog kompromisa sa pristašama te doktirne, na taj način da preuzmemo njihovu frazeologiju o sovjetima, diktaturi ili revoluciji, koja (frazeologija) svakako za razne zemlje ima različit smisao" (naglašeno u originalu - prim. S. D.). „Pametno i taktično“, Narodno jedinstvo, br. 82, 23. april 1920, 2.

„Molim vas, gdje je bio atentat? - čujete svaki čas pitanje prolaznika, koji iskorištava svoje odmjereno vrijeme da, pored ostalih, vidi i ovo najznamenitije mjesto.“ „Po Sarajevu“, Narodno jedinstvo, br. 33, 19. februar 1920, 2.

29 U Hadžićima je živio Gavrilov brat Jovo Princip.

30 Odbor za spomenik Principu u Hadžićima je saopštio da se dosadanji predsjednik g. Risto Samouković radi slabog zdravlja zahvalio na predsjedničkom mjestu, a na njegovo mjesto izabrao je odbor na sjednici od 29. januara o. g. gosp. dra Bogdana Vidovića, advokata iz Sarajeva. „Iz odbora za spomenik Principu u Hadžićima“, Narodno jedinstvo, br. 25, 9. februar 1920, 3. Iz ovog odbora su u sarajevski kooptirani Tane Trifković, učitelj iz Pazarića, Branko Kašiković, trgovac iz Hadžića, Petar Lalić, sveštenik iz Blažuja, i Simo Njego, težak iz Blažuja. „Apel Odbora za prenos kostiju vidovdanskih heroja“, Narodno jedinstvo, br. 95, 10. maj 1920, 3. 
akademičarima, okupljenim u društvu Skerlić u Pragu, da su ekshumirane i prevežene u Terezin kod Praga i kosti trojice seljaka, pomagača atentatorima, koji su bili sahranjeni u Melersdorfu kod Beča, te da su „kosti sve šestorice naših mučenika, spremljene u posebnim sanducima, čekajući da ih po završetku sletskih svečanosti u Pragu naši sokoli prenesu u otadžbinu“. ${ }^{31}$ Na praški svesokolski slet, u prijateljsku Češku, poslala je vlada Kraljevine 25. juna 1920. visoku delegaciju, ${ }^{32}$ a za preuzimanje zemnih ostataka atentatora bosanska zemaljska vlada svoje izaslanike nižeg ranga. ${ }^{33}$

Do tada je uvođenje Principa i drugova u svetački panteon za javnost izgleda već bilo gotova stvar. Ta ubrzana „spoznaja“ vlasti o Principovoj nacionalnoj vrijednosti i njegovo učitavanje u religiozno, te nacionalno-religijska konstrukcija njegovog novog identiteta dobila je na neupitnoj važnosti u toj mjeri da se i nadalje u kolektivnoj nacionalno-religijskoj zajednici, pa i u ostalim, više i ne preispituje. Nakon ne tako davne ekskomunikacije, sada se „vraćanjem“ u simboličnu religijsko-nacionalnu kolijevku neutralizovao njegov potencijalni revolucionarni naboj, a sakralizacijom su mladobosanci prihvaćeni bez njihovog revolucionarnog sadržaja.

Za dan sahrane određen je 7. juli, ${ }^{34}$ u pravoslavnom kalendaru Sv. Jovan, koji je po tradiciji „živeo skromno hraneći se biljem, bubama, skakavcima i medom divljih pčela, a odevao u haljinu od kostreti“ i smatrao

31 „Prenos kostiju vidovdanskih heroja“, Narodno jedinstvo, br. 123, 18. jun 1920, 3.

32 Zvaničnu delegaciju sačinjavali su dr Momčilo Ninčić, ministar trgovine i industrije i zastupnik ministra spoljnih poslova, Svetozar Pribićević, ministar prosvete, dr Tugomir Alaupović, bivši ministar i poslanik, Andra Stanić, bivši ministar i poslanik, dr Ivan Oražen, advokat iz Ljubljane i predsjednik Jugoslovenskog sokolskog saveza. U Pragu su im se pridružili poslanik u ovom gradu dr Ivan Hribar i u ime vojske tamošnji vojni ataše. Glas naroda, br. 269, 24. jun 1920, 3. U službenim novinama se kao zastupnici kraljevske vlade pominju i general Živojinović, predstavnici parlamenta Vilder, Lorković, Budisavljević, Svrzo, Jagić, Džamonja i drugi. Prag je ugostio i profesora dr Stojanovića, splitskog gradonačelnika dr Tartalju, prof. Cvijića, prof Žujovića i Marjanovića. Deputacija je vrlo svečano dočekivana, od granice, preko Budjejovica, Tabora i Beneševa, pa do specijalnog pozdrava, u ime vlade, ministra spoljnih poslova dr Beneša, gradonačelnika grada Praga Baksa i starješine Češke obec dr Hajnera. „Proslava Vidovdana“, Narodno jedinstvo, br. 130, 30. juna 1920, 2-3.

33 Izaslanici su bili: Milan Blažeković, načelnik poljoprivrednog odjeljenja, Stevo Žakula, šeflikvidacije Narodne obrane, i dr Bogdan Milanković, profesor, kao delegati zemaljske vlade za Bosnu i Hercegovinu. Kao delegat gradske opštine otputovao je član opštinskog odbora Stevo Marković, profesor, kao delegati iz štampe Stevo Dmitrović, šef Presbiroa, i Jovan Šošić, urednik Srpske riječi. „Svesokolski slet u Pragu“, Narodno jedinstvo, br. 126, 22. jun 1920, 2.

34 Na sjednici proširenog Odbora održanoj 24. juna rečeno je da će to biti „po svoj prilici“ 7. juli, a program ceremonije nije još uvijek bio u potpunosti završen. „Društvo za prosvećivanje žene i zaštitu njenih prava“, Narodno jedinstvo, br. 128, 25. jun 1920, 3. 
se uzorom karakternosti, poštenja i nevinosti, ali i predskazivačem apokalipse i usamljeničkog života. Sa Principovom usamljenošću bio je kraj, on sa svojim prijateljima postaje dio kolektiviteta, pa bi po pisanju štampe u tom momentu neupućeni mogli zaključiti da su ih svi društveni slojevi uvijek podržavali. „Đaka-omladinca vaspitao je učitelj, pomagao trgovac, kuražio Soko, odhranio težak. Zar nisu svi sastavni delovi i svi pravci našeg nacionalnog rada predstavljeni u ovih devet mučenika-heroja. Za jednu ideju, za jedan cilj svi, razjedinjeni dužnostima i vrstama rada ipak su se našli $\mathrm{z}$ a j e d n o u času kad je trebalo oglasiti prve naše pobede“. Bile su to „krute i markantne fizionomije isklesane iz našeg bola i rođene iz utroba majki koje nisu one sa Zapada, no one sa Balkana, silne u patnji, veličanstvene u ljubavi“. 35

Na ovom mjestu granice zajednice se čas preciznije određuju, čas kostima proširuju. „Tek što smo bili opjevali i slavom ovjenčali Vidovdane Kosovske, Vidovdane balkanskih ratova, došao je opet Vidovdan 1914. M i l o š e v a d u š a probuđena u Gavrilovoj, progovara opet osvetom, za cio narod za patnje svih Srba, Hrvata i Slovenaca. Hram se proširuje jer treba da primi nove Osvetnike hram Vidovdanski se poljepšava jer novi redovi heroja, sa oreolima slave i vjencima pobjede na glavi ulaze u svetište da čuvaju našu slavu. A Hram postaje sve veći i veći“. ${ }^{36}$ "U svim krajevima našeg silnog i moćnog kraljevstva odjeknuće pjesme Vidovdana; u svakom domu naroda koji je svojim kostima odredio granice svoje samostalnosti, čuće se pjesma koja će slaviti Vidovdanske heroje. ${ }^{137}$ Pomenuto proširenje nacionalnog hrama korespondira sa politički poželjnom idejom jedinstva "troplemenog naroda“, odnosno Principovim iskazanim jugoslovenstvom, ali značajno naglašava odakle to jedinstvo crpi snagu i kome pripada slava.

Da kojim slučajem ne bi bilo zabune, radikalska Srpska riječ, novine tadašnje vladajuće partije, potvrđuje Principovo „usvajanje“ i tekstom „Kostima naših heroja. Uspomene i reminiscencije“: „Baš u to vrijeme (na Vidovdan 1914. - prim. S. D.) počeše da gruvaju silni topovi, da oglase dolazak onoga, ko je prijetio malenoj Srbiji, ko je htio rat, (...) Kao Hristos na Golgotu prolazio je Princip. (...) Na Vidovdan 1389. nestalo je Srpske Carevine, a Vidovdan 1914. Pincipov Vidovdan, predskazao je propast sil-

35 Jovan Palavestra, „Gavrilo Princip i drugovi“, Narodno jedinstvo, br. 129, 25. jun 1920, 2-3.

36 Uz naslov na prvoj stranici „U Vidovdanskom hramu“ slijedi i moto: „Danas treba da se u nacionalnom, Vidovdanskom hramu pevaju mučenicima psalmi zahvalnosti“. Jovan Palavestra, „U vidovdanskom hramu“, Narodno jedinstvo, br. 129, 26. jun 1920, 1.

„Vidovdan - narodni praznik“, Narodno jedinstvo, br. 129, 26. jun 1920, 3. 
ne Austrije. Na Kosovu ubi Miloš Obilić cara Murata silnog, misleći da će time spasti od propasti Srpsko Carstvo. Tako veli istorija, a g. 1914. ubi Princip Ferdinanda u Sarajevu, i ma juć i pred oči ma is ti cilj.“38 Na ovaj način Princip se uvlači u krug srpskih nacionalnih heroja, postaje jedan u nizu onih koji potvrđuju kontinuitet slobodarskog duha srpskog naroda, utemeljen u kosovskom mitu, ${ }^{39}$ kome se oduzima personalni izbor i isključuje iz savremenih slobodarskih ideologija koje su uključivale za tadašnju vlast nepoželjnu ideju revolucije. Ona se sa njegovim „svetačkim" tronisanjem nastoji izbrisati iz kolektivnog sjećanja ne samo iz bosanskohercegovačkog višenacionalnog društva kao slobodarska za cijeli kolektivitet nego se istovremeno, uključenjem Principa i drugova u ekskluzivni srpsko-pravoslavni krug, nastoji naglasiti superiornost srpskog doprinosa za stvaranje „slobodne i prostrane otadžbine“, koji je pri tome „viševjekovni“. Preoblikovanje butnovnika u sveca, njegovo uključenje u religiozni krug ne dopušta preispitivanje, a ekskluzivno pravo vlasti je, pa i svake naredne, da tumači i plasira mitološki, pa time i latentno promjenjivog značenja identitet Principa i njime manipuliše, ${ }^{40}$ izolujući ga od istorijske stvarnosti. Na ovaj način vladajuća elita uspješno "guta“, a tako i neutrališe svaki nepoželjan sadržaj, uvlačeći ga u vlastiti nacionalno-religijski sistem.

Ovako pripremljeno Sarajevo dočekalo je posmrtne ostatke mladobosanaca, čime je započeo i formalni proces ritualizacije njihove vrijednosti i pripadnosti, koja je, kako će se vidjeti, do kraja ostala prilično nejasna. ${ }^{41}$ Zastavama okićenim privatnim kućama, sa mnoštvom građana i seljaka ispred zgrade glavne pošte, gdje je stigao „naročiti željeznički voz“42 i govorima Steve Žakule, starješine sokola, i Luje Novaka, potpredsjednika Odbora, koji su se zahvalili čehoslovačkom narodu ističući njegove zasluge, pokrenuto je zataškavanje indikatora simptomatične lojalnosti nacionalnoj zajednici i njegovog redefinisanja u „ispravnom“ pravcu. Nakon toga su na zajednička kola, „koja su bila ukrašena morem cvijeća“ i svije-

38 „Kostima naših heroja. Uspomene i reminiscencije“, Srpska riječ, br. 130, 6. jul 1920, 1.

39 Ivan Čolović, „Sarajevski atentat i kosovski mit“, Sarajevski dugi pucnji 1914. Događaj-narativ-pamćenje, (Zenica: Vrijeme, 2015), 53.

40 Wolfgang Müller-Funk (Beč), „O znakovitosti datuma 1914. Čitanje Krausa, Musila, Rotha, Andrića i Iwaszkiewicza kroz prizmu Hansa Blumenberga“, Sarajevski dugi pucnji 1914, 69.

41 Erik Hobsbom, „Uvod: kako se tradicije izmišljaju“, Izmišljanje tradicije, ur. Erik Hobsbom, Terens Rejndžer, (Beograd: Biblioteka XX vek, 2002), 19, 22.

42 Voz je dopremio zemne ostatke Gavrila Principa, Nedeljka Čabrinovića, Trifka Grabeža, Mitra i Neđe Kerovića i Jakova Milovića. 
ćama, smješteni doveženi lijesovi i onih „mučenika“ koji su bili pokopani u Sarajevu, ${ }^{43}$ pa je, u povorci predvođenoj trojicom trubača i barjaktara, dobrovoljcima, djecom, sokolima i čehoslovačkom muzikom, obalom Miljacke procesija otišla na mjesto atentata, gdje je govor održao Vasilj Grđić, jedan od osuđenika na veleizdajničkom procesu i sekretar Prosvjete. Horovi pjevačkih društava, srpske Sloge i jevrejske La Lire otpratili su sa pjesmom Hej trubaču povorku, koja je, po novinskom izvještaju, Kralja Petra i Aleksandrovom ulicom stigla na koševsko groblje, gdje ju je dočekao rektor srpsko-pravoslavne bogoslovije g. Tomo Popović sa sveštenstvom, „koje je odslužilo opijelo uz pratnju pjevačkog zbora Sloge“. Oduševljen govor u ime omladine održao je student Dušan Smiljanić, budući arhitekta, a potom se ceremonija završila oprosnim govorom Stevana Žakule i jednog od učesnika atentata Muhameda Mehmedbašića. ${ }^{44}$ Lijesovi su uz signale fanfare i pjevanje Sloge spušteni u zajednički, opet privremeni grob.

Završnicu izvještaja o sahrani činio je komentar: „Ovoj svečanosti nijesu prisustvovali niti predstavnici građanskih niti vojnih vlasti.“ ${ }^{45} \mathrm{Na}-$ kon početnog elana podrška se vlasti, pa čak i gradske, ${ }^{46}$ negdje izgubila, pa se svela na privatnu inicijativu. Kada se zvanična vlast odrekla Principa, nije to bilo teško učiniti drugima. Hrvatska sloga bez komentara dosljedno prenosi objave Odbora, ${ }^{47}$ dok muslimanska Pravda dan uoči sprovoda donosi kratku ali toplu novinarsku $\mathrm{crticu}^{48} \mathrm{Za}$ odsustvo organizovanije ak-

43 Danilo Ilić, Veljko Čubrilović i Miško Jovanović su bili osuđenici na smrt i obješeni 5. februara 1919. godine, Marko Perin je bio jedan od saučesnika atentatora i osuđenih mladobosanaca, a Bogdan Žerajić atentator na vojnog poglavara generala Marijana Verešanina, koga je pokušao ubiti na dan otvaranja bosanskog sabora 15. juna 1910. godine. Nakon neuspjeha izvršio je samoubistvo.

44 „Svetli dan“, Glas naroda, br. 277, 9. jula 1920, 1; „Pogreb kostiju vidovdanskih heroja“, Hrvatska sloga, br. 138, 8. srpnja 1920, 3.

45 „Sahrana kostiju žrtava slobode“, Narodno jedinstvo, br. 136, 7. juli 1920, 2. - Za razliku od njih, pjesnik Aleksa Šantić je mladobosancima posvetio pjesmu, koju je napisao 6. jula ležeći u državnoj bolnici. „Na dan prenosa kostiju Gavrila Principa i njegovih drugova", Narodno jedinstvo, br. 135, 6. juli 1920, 2.

46 Proglas gradskog poglavarstva građanima Sarajeva da 7. jula prisustvuju prenosu posmrtnih ostataka vidovdanskih junaka. Poziv je uputio potpredsjednik Opštine dr Zistler. Preporučuje se odijelo „narodno svečano ili crno“, te se mole odbornici „da se ovom pozivu neizostavno odazovu, a ako bi, kogod bio zapriječen da me na vrijeme o tom pismeno obavjesti“. Historijski arhiv Sarajevo (HAS), Gradsko poglavarstvo, dok. br. 21279, 23497, 1920.

47 „Vidovdanski mučenici“, Hrvatska sloga, br. 136, 6. srpnja 1920, 2; „Prenos kostiju vidovdanskih heroja“, Hrvatska sloga, br. 137, 7. srpnja 1920, 2; „Pogreb kostiju vidovdanskih heroja“" br. 138, 8. srpnja 1920, 3.

48 „Od dulje se vremena sprema osobito Sarajevo, da se što dostojnije dočeka ostatke vidovdanskih junaka, pa će taj dan po svojoj značajnosti biti jedan veliki dan u histo- 
cije Srpska riječ će formalno okriviti Odbor, izabran „iz uskog kruga ljudi“, pa je zbog toga „ono što je učinjeno i priređeno bila sponatna manifestacija narodnog poštovanja prema herojima", najavljujući opširniji osvrt, do koga nije došlo, ali je u „šaljivom osvrtu“ primjećeno da su na sahrani postavljeni vijenci onih ustanova koje su opljačkane 1914. godine, a da nema „vijenca ni od jednog ratnog milijonera, a oni su bar dužni Principu, jer da nije bilo atentata ne bi došlo do rata i oni ne bi postali ratni milijoneri““49

Ozbiljniju analizu, ali i pogrešno procjenjujući da će predstavnici vlasti podržati bar ceremoniju sahrane, dao je socijaldemokratski list Glas slobode, iako protivnik individualnog nasilja, podržavajući ovog puta borca protiv socijalnih nepravdi, nasilnog pokretača promjena vrijednosti i ponašanja, vođenog opravdanim ogorčenjem:

„Švercerima, trgovcima sa čašću, obećenjima i položajem, bivšim najponiznijim i najvernijim slugama crnožutog režima, a današnjim nenadmašnivim patriotama i 'državotvornim elementima', pruža se danas prilika da svečano mogu manifestovati sav žar svoga 'patriotizma', svu svoju vruću 'ljubav' prema ovome narodu, koji ume tako herojski, sa takvim samopožrtvovanjem prolevati krv svoje dece, dok su se oni mogli bogatiti, da bi oni mogli što brže i bolje pretvoriti tu krv u pare da s njima ispunjavaju svoje kase, ili da na račun te krvi stiču što bolje i masnije položaje, sa kojih bi tom istom narodu mogli posle učiniti što više zla izvršivši nad njim što više nasilja, oduzeti mu sva prava, koja bi se usudio da traži. ${ }^{\text {“50 }}$

riji našeg mučeničkog naroda. Dugo vremena su njihove kosti trunule u tuđini, pa će sutra, kad budu spuštene u krilo rođene grude naći konačno svoj spokoj. Slava im!“ „Prenos kostiju vidovdanskih junaka“, Pravda, br. 69, 6. jula 1920, 3.

„Unaokolo“, Srpska riječ, br. 132, 9. jula 1920, 1.

50 „Danas u Sarajevo stižu kosti onih nekoliko mladića, oduševljenih nacionalnih revolucionara, koji žrtvovaše sami sebe, svoju mladost i svoju budućnost, u nadi da će jedan njihov pregalački gest moći ovom narodu doneti slobodu, rastočiti okove u kojima ga je održavalo gospodarstvo tuđinskih imperijalističkih osvajača. (...) Mislili su na jadnoga, bedom izmučenog bosanskog kmeta, kome je valjalo svojim trudom hraniti age i begove, muslimanske, katoličke i pravoslavne. Mislili su na sve one koji su se patili i mučili, na sav porobljeni radni narod sa sela i grada, nadajući se da se posle propasti crnožutog režima neće više niko naći ko bi se usudio da ga zameni na grbači radnoga naroda. (...) Ali samo jedan trenutak posmatranja onoga što rade novi gospodari, samo jedan pogled na truleži, korupciji, pokvarenosti onih koji danas ugnjetavaju 'oslobođeni' narod, dovoljan bi bio da učini ono što muke i patnje robijaškog života nisu mogle učiniti: ubili bi u njima veru da su žrtvujući sebe poslužili delu narodnog oslobođenja. (...) U mesto zemlje slobode i pravde, u mesto zemlje u kojoj narod slobodno živi bez da na svojim leđima nosi svoje sopstvene ugnjetače, u mesto da vide kako sam narod upravlja svojom sudbinom, jednom rečju: umesto slobodne zemlje sa slobodnim narodom - oni bi videli zemlju najmračnije reakcije, bespravlja i nepravde, videli bi narod pogrbljen pod teškim teretom nepravde, nasilja i zala što 
Oni kao da su znali za Principovu viziju poslijeratne Bosne. „On pred atentat, već potpuno spreman da učini svoj poslednji gest, s gorčinom gledao u budućnost. - Žrtvovaće se nekoliko nas, govorio je, - nestaće nas kao prašine u vetru, ali iza nas će ostati ono što je najgore: Blatnjava površina. Ako bude kakvih plodova, biće njihovi. ${ }^{\text {"1 } 1}$

Protiv takvih Glas slobode upućuje „Poziv radnicima na opštu javnu protestnu skupštinu" - protiv napada buržoaske reakcije na osamsatno radno vrijeme i nedeljni odmor u trgovačkim radnjama, a dva dana kasnije pozvali su svoje čitalaštvo: Proleteri, branite svoja prava!, te najavili stalnu rubriku pod nazivom Komunistički omladinski pokret, ${ }^{52}$ što se vlastima vjerovatno nije svidjelo.

Društvo ipak nije moglo biti imuno na socijalnu bijedu i pozicioniranje društvene oligarhije, pa su i cenzorima promakle riječi iz službenih novina u članku povodom Francuske buržoaske revolucije, čija je godišnjica obilježena par dana kasnije: „Jedna velika ideja se ne ostvaruje jednim jedinim udarom, a udari i revolt masa nikad ne bijahu staložene pojave sa trajnim učincima. Ideja koja traži svoju pobjedu trza se po prirodnom i socijološkom zakonu kroz nekoliko katastrofalnih trzaja i erupcija, dok ne pobijedi. Primjer imamo i danas eno u Rusiji, eno u Njemačkoj, eno u Madžarskoj, koja je za ovo kratko vrijeme poslije rata promijenila nekoliko režima. (...) Nije tu riječ o formi države, kako bi se to površno moglo misliti, nego o položaju čovjeka u državi“, sa završnicom-hvalopsjevom oslobođenom i ujedinjenom narodu Kraljevine koji „može da se s pravom pridruži slavi ove velike francuske obljetnice kao slobodan i velik građanin svoje slobodne i velike kraljevine “. ${ }^{33}$

Međutim, samo naivnima se moglo učiniti da je izostanak podrške vlasti bio slučajan. Degradacija „vidovdanskih heroja“ je svoj značajan, ali za pojedine društvene skupine vrlo bolan izraz dobila nakon samo pola godine, prilikom pomena u crkvi, gdje je odziv građanstva bio „besprimerno mizeran“. ${ }^{44}$ Sljedećih godina, pored dosljednih sokola, mlado-

mu ga na leđa tovare novi gospodari udruženi sa slugama starih; videli bi narod kome se oduzimaju sva njegova najosnovnija prava i čiju sudbinu po svome ćeifu i kaprisu kroji nekoliko udruženih uzurpatora, političkih šarlatana, špekulanata i švercerskih jataka, videli bi zemlju u kojoj se u mesto slobode zacarila razuzdana, izbezumljena tiranija kapitalističko-čaršiske, begovske i klerikalne oligarhije." Glas slobode, god.X, br. 141, 7. jula 1920, 1.

51 Borivoje Jevtić, „Gavrilo Princip”, Glas naroda, br. 272, 1. jula 1920, 2.

52 Glas slobode, god. X, br. 143, 9. jula 1920, 1; br. 144, 10. jula 1920, 3.

53 „14. jula 1789“, Narodno jedinstvo, br. 140, 14. jula 1920, 1.

54 „Osim bliže rodbine koju najviše boli srce, osim nekoliko Sokolica i Sokolova koji svoje heroje najiskrenije vole, i osim nekoliko veleizdajnika, njihovih sapatnika, 
bosanaca su se sjećale samo marginalizovane skupine - omladina, ${ }^{55}$ ženska, pa i pjevačka udruženja, ${ }^{56}$ te podsjećali novinari i književnici, boemi iz Semizove vinarije, gdje su se nekoć okupljali zavjerenici, a Princip ju je posjetio noć uoči atentata. Oni koji su preživjeli, zabilježeno je, ponekad su se okupljali i evocirali te mladalačke dane. ${ }^{57}$

Za dalje planske promjene Principove simboličke revolucionalne slike, poslužio je njegov poetski senzibilitet. Radikalski list tekst na prvoj stranici uoči Vidovdana sljedeće godine naslovljava „Gavrilo Princip kao pesnik“, sa podnaslovom „Sećanje na vidovdanskog heroja“, te ne/očekivano ne pominje stihove sa terezinskog zida, već kratki esej gimnazijalca Principa Izlet na Bjelašnicu, pisan 1911. godine, koji odaje „duboku i osjetljivu dušu i prirodu kojoj imponira sila i snaga. On se prema veličanstvenosti i moći prirode osjeća mali i nemoćan, ali ipak kao da priželjkuje da bi bio rad uhvatiti se u koštac - sa čime velikim, što prelazi njegove moći", te

nikoga više nije bilo ni u crkvi ni na groblju. To je bilo sramno od Sarajeva, koliko je god dugo, široko i visoko (...) ono je, docnije, tražilo i našlo mnogo lepih i dirljivih izgovora: Nekome je parastos zakazan odviše rano; nekome nije bilo tačno označeno vreme pomena, (...) nekoji su se čak, kao iz sna, pitali šta se to važno desilo 3. februara da se mora ići na groblje. To je, eto, naš sarajevski patriotizam - tašlihanski, piruški ili alifakovački - takvi smo, eto, mi kao čuvari i poklonici jednog velikog i svetlog groba koji je, slučajno zalutao u nežno i osetljivo Sarajevo. Među nama leži Princip, okružen svima svojim palim drugovima, a bedno Sarajevo spava, dokle mu sveštenik prekađuje zeleni grob! Duše trojice sokolskih heroja i mučenika lebde na strašni dan svoga stradanja nad tužnim vrbama koševskog groblja, a apatično Sarajevo zeva i proteže se u mamurluku svoga patriotizma! Može li išta biti stidnije i sramnije za jednu varoš (...) To sam pero zaželeo da dočepam i ja dana 3. dana februara pa da, vidno za celo Srpstvo i Jugoslovenstvo, ispišem na plavetnilu neba reči svoga sokolskog i čovečanskog bola toga dana: - Sarajevo, ognjem izgorjelo! - Stevo Žakula, star. Župe.“ „Pomen herojima 3. februara", Narod, br. 8, 19. februara 1921, 2.

55 „Jutros su se sarajevski sokoli i omladina sjetili trojice svojih drugova, koji su, na današnji dan u početku rata izdahnuli na vješalima austrijskih okupatora. Miško Jovanović, Veljko Čubrilović i Danilo Ilić platili su, na današnji dan, glavom djelo koje se može označavati razumnim ili nerazumnim, ali je ono, nesumnjivo bilo izraz jednog poštenog zanosa omladinske generacije, koja je sva sagorila za ideale nacije koja je bila u teškoj i neravnoj borbi za slobodu. Slava im!“ „Pomen atentatorima“, Večernja pošta, br. 1677, 4. februar 1927, 6.

56 „Sa osnivačke skupštine pjevačke župe 'Gavrilo Princip'“, Jugoslovenski list, 26. novembar 1940, 5. - Izvjesna Organizacija Vidovdanskih heroja javlja da „izdaju svoj džepni kalendar sa 7 herojskih slika i sa 8 vrlo lijepih pjesama." Večernja pošta, br. 2239, 5. januar 1929, 6.

57 Prilikom drugarskog okupljanja predratne jugoslovenske nacionalno-revolucionarne omladine za podsjećanje predavanja su održali: Borivoje Jevtić, književnik, Danilo Dimović, advokat iz Zagreba, dr Mirko Kus-Nikolajević, Vojislav Bogičević. „Pred sastanak omladinaca iz 'Mlade Bosne”“, Večernja pošta, br. 1927, 2. oktobar 1935, 4. 
u tišini noći „sa prigušenim jaukom klikće: 'Oh, misli, vizije i iluzije moje!' - To su izrazi srca, koje mnogo osjeća, čije su želje bezgranične, ali sve to zagorčeno ledenim saznanjem o slabosti i nemoći čovjekovoj. “58 Isticanje romantične prirode, koja, kako se obično smatra, zamagljuje svako racionalno postupanje, pa i svjetski poznatog prevratnika i atentatora, govori o službenoj poruci vlasti da je njegov pomućeni razum bio vjerovatno razlog iskazivanja ishitrene, ali poremećene ljudske volje, a ne djelo božanske promisli i istorijskog kontinuiteta, pri tome ne pominjući, no imajući na umu: „Revolucija nikada ne dolazi iz očajanja kao što se pogrešno misli (...) nego iz revolucionarne misli koja raste u narodnoj duševnosti bogate entuziazmom, velike unutrašnjim životom ". ${ }^{59}$ Ipak, izgleda da je postavljanje Principa kao pjesnika „na mrtvu stražu“ nacionalno-religijske konstrukcije bio rezervni adut, ${ }^{60}$ koji kasnije nije razvijan, djelom jer je tanka ostavština bila nedovoljno uporište za željeno nacionalno-pedagoško usmjerenje, ${ }^{61}$ a djelom i radi toga što je, kako se smatra, njegova najpoznatija poetska poruka insinuirala sasvim neki drugi, neželjeni pravac: „Naše će sjene hodati po Beču, lutati po dvoru i plašiti gospodu“.62

Za obesmišljavanje radikalno prevratničke ideologije mladobosanaca išlo se i dalje, pa je objavljeno i posljednje pismo jednog od njih, upućeno supruzi. ${ }^{63}$

U novim okolnostima, sa proklamovanjem jugoslovenske etatističke ideologije, malo toga se za Principa promijenilo, ${ }^{64}$ a slika mladobosana-

58 Srpska riječ, br. 128, 27. jun 1921,1. - Službeni list takođe veliča Principa - pjesnika i romantičnu dušu. „A niko možda i ne zna da je i on imao svojih pjesničkih snova, svojih čežnja i dugih lutanja u noćima bez sna; niko ne zna da je i on bio jedan od onih koji su oko sebe osjećali ljepotu života, prirode, svega što je u pokretu.“ „Gavrilo Princip i priroda“, Narodno jedinstvo, br. 7,13. januar 1920, 3.

59 Veselin Masleša, Mlada Bosna, (Sarajevo: Izdanje Državnog izdavačkog preduzeća Bosne i Hercegovine, 1945), 111, (fusnota 4).

60 O literarnim izvorištima i nasljeđu mladobosanaca više vidjeti: Predrag Palavestra, Književnost Mlade Bosne, I-II, (Sarajevo: Svjetlost, 1965).

61 Ivan Čolović, „Kultura, nacija, teritorija“, Balkan - teror kulture, (Beograd: Biblioteka XX vek, 2008), 91.

62 Dedijer, Sarajevo, 1914, 614.

63 „Oproštaj Miška Jovanovića“, Srpska riječ, br. 20, 1. februar 1921, 1.

64 Njegovo ime nije pomenuto ni prilikom okupljanja „predratne nacionalističke omladine“, prilikom manifestacije osvećenja jugoslovenskih zastava u Sarajevu, kada su preživjeli i već situirani „omladinci“ dali izjavu potpore vlasti i kralju za sprovođenje politike ,jugoslovenskog integralnog jedinstva“. „Prilikom istorijskog akta izmjene vojničkih zastava predstavnici predratne jugoslovenske nacionalističke omladine koji se nalaze u Sarajevu klanjaju se sa dubokom poštom starim pukovskim zastavama bivše Kraljevine Srbije kao simbolu onog herojskog i slavnog napora koji je doveo do ostvarenja današnje Jugoslavije. Pozdravljamo ovaj akt smatrajući da je 
ca je i dalje mistično-religiozna. ${ }^{65} \mathrm{U}$ najavi otkrivanja spomen-ploče krajem januara 1930. godine, ona još uvijek nije za javno promovisanje, pa je navedeno da će to biti „intimnog karaktera, kojemu prisustvuju samo pokojnikovi prijatelji i rodbina, bez sudjelovanja društava“. O svečanoj ceremoniji ni govora, pa ni prisustva sokola. Otkrivanju ploče 4. februara 1930. prethodio je parastos u Sabornoj crkvi, a akademija na Narodnom univerzitetu je bila odgođena. ${ }^{66}$ Izvještaj sa tog „tihog i mirnog“ pomena, donesen u rubrici Gradske vijesti, u dnu stranice jednog dnevnog lista, navodi da je Vasilj Grđić, stari nacionalni borac, pripadnik lijevog krila prve generacije intelektualaca i u novoj političkoj sceni opozicionar, bivši osuđenik na smrt sa veleizdajničkog procesa, pozvao prisutne članove porodice i prijatelje „da provedu dvije minute u dubokoj šutnji pred pločom“. Hamdija Nikšić, „nacijonalista iz predratne generacije, skinuo je na to pokrov s ploče. Kad je minula šutnja kliknuli su prisutni tri puta 'Slava!' i onda se tiho razišli.“ ${ }^{\text {67 }}$ Principovo jugoslovenstvo nije bilo potrebno ne samo tadašnjim vlastima nego, i pored manifestovane ideološke propagande, ni nacionalnim i kulturnim društvima. Snažna revolucionarna sadržina Principovog čina i njegov pokušaj izmjene socijalne i državne strukture konstantna su okosnica i trajna opasnost za državne vlasti i uzrokom planske marginalizacije. Jednim djelom je to bilo i razumljivo, s obzirom na konstantno pre-

njim i aktima od 6. januara i 3. oktobra ideja jugoslavenskog integralnog jedinstva postala osnovicom državne politike. Za tu ideju se jugoslavenska nacionalistička omladina zalagala potpuno i bez kompromisa i prije rata. Za vrijeme rata ona je za nju podnijela žrtve, a iza Oslobođenja nastojala da ta ideja dođe do izraza u svim oblicima društveno-političkog života." Potpisnici su bili: prof. Husein Brkić, prof. Uroš Čović, Radmilo Grđić, novinar, Hamza Humo, književnik, Marko Ilić, direktor oblasne zadruge za polj. kredit, Borivoj Jevtić, književnik i dramaturg, dr Gojko Krulj, publicista, Marko Marković, književnik, prof. Nika Miličević, publicista, Hamdija Nikšić, priv. činovnik, Jovan Palavestra, novinar, Stjepan Redžo, činovnik, Viktor Rubčić, novinar, Rade Starović, sudija. „Pozdrav predratne nacionalističke omladine jugoslovenskim zastavama“, Jugoslovenski list, br. 206, 6. septembar 1930, 5.

65 Tako Večernja pošta piše: „dole u redovima naroda koje je gušio sram i težina robovanja i mučila jedna mistična vizija Slobode, sabirali su se izabranici munje za dušmana, i onda su u bljesku tih munja zasjali likovi Principa, Ilića, Čabrinovića i drugova. Na 3. februara 1915., trojica od njih, sokoli Miško Jovanović, Danilo Ilić i Veljko Čubrilović okončali su živote na austrijskim vješalima, na Golgoti, koja nije dugo čekala na Vaskrsenje." Večernja pošta, br. 2283, (Sarajevo), 2. februar 1929, 5.

66 Jugoslovenski list, br. 25, 31. januara 1930, 9. - Najavljeno, a neodržano predavanje je trebalo da bude u organizaciji sokola i sa govornicima Stevanom Žakulom, dr Đurom Ostojićem i Emilom Petrovićem. Jugoslovenska pošta, br. 207, 30. januar 1930, 3. 
ispitivanje odgovornosti za rat, ${ }^{68}$ naglašeno naročito prihvatanjem novog plana za njemačke reparacije tih dana. Na valu tih događaja bilo je moguće da njemačka i italijanska štampa prošire „vijest po cijelom svijetu da je na mjestu sarajevskog atentata na svečani način otkriven spomenik ubici“, što je dalo priliku za nove napade protiv Jugoslavije, čemu se pridružila i britanska štampa, koja je zamjerila jugoslovenskoj vladi „što nije preduzela mjere protiv ove privatne 'proslave' atentata". 0 ovim interpretacijama strane štampe, koje su bile u potpunom nesrazmjeru sa stvarnošću, autor teksta u dnevnim novinama ukazuje na „okolnosti - koje su naročito važne za inostranstvo - pod kojima su se Princip i njegovi drugovi riješili na ovaj čin, koji je bio očajnički uzvik nacionalne Bosne pod teškim valjkom austro-njemačke ekspanzije prema Istoku, i austrijanštine, ovog opasnog otrova, koji je trovao jugoslovenski narodni organizam“. U daljem razlaganju autor sumira da „to nije bio samo Princip - čovjek, koji je oborio napadača, to je bio princip - načelo, da narod kao i pojedinac u slučaju opasnosti svoga života ima pravo da se brani“.69

U duhu odbrane, vidovdanskih heroja i Gavrila Principa sjetili su se tek devet godina kasnije, u vremenu kada je Sporazumom CvetkovićMaček Bosna i Hercegovina već bila „načeta“ i potresena brojnim i bur-

68 Jednu takvu raspravu uzrokovalo je i javljanje barona Kolasa. U najavi serijala-odgovora „našeg književnika i upravnog sudije g. Milana Ćurčića baronu Collasu na poznati njegov napis u njemačkoj reviji 'Kriegsschuldfrage'. S jakim argumentima u ruci, citirajući zvanične sudske spise, g. Milan Ćurčić dokazuje apsurde njemačke teze. Naše čitaoce upozoravavmo na ovaj napis i iz razloga, što ujedno daje pravu, tačnu i vjernu sliku tadanje idealističke nacionalne omladine. U dokumentima, što ih iznosi g. Milan Ćurčić, spominju se i mnoga lica koja su našim čitaocima poznata. Tako pored Collasa, Bilinskoga i dr. spominju se A. Schek-Vugrovečki, dr Milivoj Simić, dr. Horländer, sudija Naumović, dr Smodlaka, prof. Hakija Hadžić, prof. Prelog, prof. Biro, predstojnik Mihalica i dr. - Od revolucionarnih duhova spominje se čitava legija omladinaca Srba, Hrvata i muslimana, koji i danas žive u našoj sredini. - Otkrića g. Milana Ćurčića, sakupljena s mnogo mara iz sačuvanih dokumenata i direktno lično od pojedinih lica, biće također i jedan značajan prilog našem ministarstvu spoljnih poslova, koje prati sva njemačka 'dokazivanja' o odgovornosti rata.“ - „Bosnische Wegsspuren“, Večernja pošta, br. 1677, 4. februar 1927, 6.

69 „Teška je ironija sudbine, da je još danas trebalo dokazivati Evropi, da mladi idealista Princip nije bio obični ubica, nego dobrovoljna žrtva, koji nije napadao nego se samo stavio u odbranu protiv napada na život svog naroda. Austro-Ugarska je već davno prije svjetskog rata počela otvorenu borbu protiv Jugoslavena, unosila među njih razne vještačke sporove, iskorišćavala vjerske razlike, oružala se protiv Srbije, vodila ekonomsku i političku borbu, i svim mogućim sredstvima podržavala na Balkanu vatru na kojoj je trebala da izgori Srbija i Jugoslaveni. U otvorenoj borbi koju je na taj način Austrija vodila na Balkanu, proliveno je mnogo jugoslavenske krvi; nije dakle čudnovato što je u ovoj nejednakoj borbi pao i pucanj protiv austrijskog nadvojvode." Jugoslovenski list, br. 46, 25. februar 1930, 5. 
nim političkim nesuglasicama oko njene budućnosti, a dalje komadanje Jugoslavije bilo izvjesno, ali ne u pravcu kojem se politička javnost nadala. Agresivna njemačka sila već je napravila prvi osvajački korak septembra 1939. godine, koji se neće uskoro zaustaviti, nego će prouzrokovati novu svjetsku kataklizmu zvanu Drugi svjetski rat.

Te jeseni, 29. oktobra 1939, održane su svečanosti na koševskom groblju u Sarajevu povodom osvećenja Spomen-kapele Vidovdanskim herojima, rađene po projektu poznatog arhitekta prof. Aleksandra Deroka. ${ }^{70}$ Tom prilikom osvećeno je i zvono, dar uglednog sarajevskog trgovca i predsjednika sprsko-pravoslavne crkvene opštine Steve Prnjatovića, koji je svojim prilogom od 170.000 dinara pomogao crkvenu opštinu da podigne kapelu. ${ }^{71}$ Nije bez značaja napomenuti da su u kriptu ugrađenu ispod kapele već mjesec dana ranije, „bez objavljivanja i tiho“, prenešene kosti mladobosanaca iz privremene betonske grobnice i da, kako je navedeno, „nju poklanja samo narod, a ne pojedinac“. ${ }^{\text {"2 }}$

Osveštenje kostiju izvršio je dabro-bosanski mitropolit Petar uz prisustvo dvanaest sveštenika, dva đakona i cijele srpsko-pravoslavne bogoslovije. Nakon osvećenja održan je i parastos ispred kapele, a mitropolit je održao „divan govor, kojim je istakao herojstvo naših junaka u istoriji i njihovu zavetnu misao koja ih je vodila Slobodi. Govor je dokumentovao istoriskim činjenicama i našom narodnom filozofijom, ističući njihov primer novim pokolenjima." Nakon njega nadahnuto je govorio i Stevo Prnjatović napomenuvši da su izvršili "još jednu dužnost" gradnjom „hrama“ za „kosti prvoboraca za naše oslobođenje“, „iz dužne blagodarnosti prema njihovoj žrtvi, prema žrtvi koju podniješe za naše dobro“, „za slobodu i za kućni prag“. „Jer, naša istorija, to je dug niz borbi. A sve te borbe, vođene one perom ili mačem - bijahu vazda vezane za snažne ličnosti. Po veličini, pa i po redu žrtve, naša najbolnija borba, borba za oslobođenje ovih krajeva ispod Austro-Ugarske vezana je - pored imena njihovog uzo-

70 Prema projektu Aleksandra Deroka, pored kapele, urađena je i kripta, unutrašanjost, polijelej, čiraci i ostali detalji.

71 Sredstva za kapelu je Stevo Prnjatović dao „kao dar na uspomenu i za pokoj duša dobrih roditelja pok. Sime i Daše i brata Rajka, zvono za uspomenu na svog zeta pok. dr Dušana Davidovića, a gđa Jula, njegova supruga poklonila je ikonu u spomen na svoga oca pok. Dimitrija Kočovića, sarajevskog trgovca“. Sestra Steve Prnjatovića, Rajka Davidović je poklonila takođe ikonu, a trgovac Mihajlo Trebić polijelej (veliki luster-svijećnjak koji stoji u sredini crkve) i čirake (svijećnjake) „u starom srpskom stilu“. - Jugoslovenska pošta, br. 3166, 23. oktobar 1939, 5.

Jugoslovenska pošta, br. 3166, 23. oktobar 1939, 5. 
ra Bogdana Žerajića prvenstveno uz imena Vidovdanskih junaka". ${ }^{73}$ Pred opasnošću od nadolazeće neizvjesnosti „pozvani“ su Princip i mladobosanci da osnaže kolektivni duh, a naročito „snažne ličnosti“ koje bi se nanovo borile za dobrobit nacionalne zajednice.

Promjenjivost pojma i slike Principa iskoristiće i vlast socijalističke Jugoslavije, pa će istaknuti njegovu revolucionarnost, „učitati“ je „odbacujući neke razumljive ali organizovanom radničkom pokretu neprimerene metode, kao što su atentati na vlastodršce ${ }^{\text {". }}{ }^{74}$ Istovremeno će u sarajevskim okvirima urbanu legendu Principa i njegov buntovnički duh donekle subverzivno podržavati generacije omladine, da bi se danas ponovno, u zatomljavanju osnovnog, revolucionarnog čina Principovog, sprovodila savremena politička instrumentalizacija, pri čemu se gubi i njegov „svetački oreol", a on se svodi samo na istaknutog pripadnika jedne nacije, odnosno na parareligijsku, odnosno nacionalno-političku svetinju. ${ }^{75}$ Ona je tu u svrhu proizvodnje perpetuirane političke stratifikacije nacionalno-religijskih tabora, naglašavanja gubitaka vlastitog nacionalnog kruga, ali što je možda još važnije, u svrhu onemogućavanja dijaloga, razaranja zajedništva, socijalne solidarnosti i zamagljivanja socijalne eksploatacije u skladu sa novim vrijednosnim paradigmama - religija, nacionalizam, kapitalizam $^{76}$ - te u krajnjoj liniji i difamacije potencijalnog omladinskog pokreta i socijalne pobune.

Bilo šta što se u prošlosti desi ne može se izmjeniti. Mijenjaju se kroz vrijeme samo stavovi, procjene, valorizuje se funkcionalnost i stečeno iskustvo, vrše se prevrednovanja istorijskih događaja i pojmova, koji nanovo govore o vremenu, društvu i duhu sadašnjice, različitom od sadržaja istoriografskih istraživanja. Gavrilo Princip i dalje ostaje trajni žižak bosanskohercegovačke prošlosti.

73 Na ploči su upisana imena: Gavrilo Princip, Nedeljko Čabrinović, Danilo Ilić, Mihailo Miško Jovanović, Veljko Čubrilović, Trifko Grabež, Jakov Milović, Neđo Kerović, Mitar Kerović, Marko Perić. Bratstvo, br. 10-11, god. XV, (Sarajevo), oktobar-novembar 1939, 188-189.

74 Čolović, „,Sarajevski atentat i kosovski mit“, Sarajevski dugi pucnji 1914, 66.

75 Ivan Čolović, „Nacionalne svetinje i tolerancija“, Balkan - teror kulture, (Beograd: Biblioteka XX vek, 2008), 21.

76 Todor Kuljić, Prognani pojmovi. Neoliberalna pojmovna revizija misli o društvu, (Beograd: Clio, 2018), 93. 


\section{Rezime}

Od Principovog čina atentata prvi su se ogradili srpski uglednici, a vrhovi Srpske pravoslavne crkve su ga stigmatizirajući ekskomunicirali iz zajednice. Nakon rata, 1920. godine, povodom prenosa Principovih kostiju i sahrane u domovini, kada su on i njegovi drugovi „vraćani“ u simboličnu religijsko-nacionalnu kolijevku, neutralizovan je njegov potencijalni revolucionarni sadržaj i potencijal. Pošto sakralizacija nije dopuštala preispitivanje, ekskluzivno pravo tadašnje vlasti, pa i svake naredne, bilo je da tumači i plasira religiozno-mitološki identitet Gavrila Principa i njime manipuliše, izolujući ga od istorijske stvarnosti. Dalju promjenu Principove simboličke revolucionalne slike sa proklamovanjem jugoslovenske etatističke ideologije 30-ih godina jednim dijelom onemogućilo je konstantno preispitivanje odgovornosti za rat. Princip i drugovi su ponovo dobrodošli da osnaže kolektivni duh 1939. godine, u kojoj je političkim turbulencijama već bila ugrožena Bosna i Hercegovina, a dalje komadanje Jugoslavije bilo izvjesno. Danas, zatomljavanjem osnovnog, revolucionarnog čina Gavrila Principa i političkom instrumentalizacijom, on se svodi na parareligijsku, odnosno nacionalno-političku svetinju, u svrhu proizvodnje perpetuirane političke stratifikacije nacionalno-religijskih tabora, ali što je možda još važnije, u svrhu onemogućavanja dijaloga, razaranja zajedništva i zamagljivanja socijalne eksploatacije u skladu sa novim vrijednosnim paradigmama (religija, nacionalizam, kapitalizam), te u krajnjoj liniji i difamacije potencijalnog omladinskog pokreta i socijalne pobune.

\section{Sources and Literature}

- Historijski arhiv Sarajevo. Gradsko poglavarstvo.

- Aleksić, Budimir. „Odjek sarajevskog atentata u Kraljevini Crnoj Gori“. Ćorovićevi susreti 2013. godine. Međunarodni naučni skup istoričara Sarajevski atentat 1914, ur. Vojislav Maksimović, Draga Mastilović, 233-246. Gacko: SPKD „Prosvjeta“, Opštinski odbor Gacko, 2014. (cyrillic)

- Clark, Christopher. The Sleepwalkers. How Europe Went to War in 1914. London: Alan Lane an imprint of Penguin Books, 2012. doi: 10.1515/hzhz-20140291

- C Čolović Ivan, „Nacionalne svetinje i tolerancija“. Balkan - teror kulture, 1924. Beograd: Biblioteka XX vek, 2008.

- Čolović, Ivan. „Kultura, nacija, teritorija“. Balkan - teror kulture, 73-111. Beograd: Biblioteka XX vek, 2008. 
- $\quad$ Čolović, Ivan. „Sarajevski atentat i kosovski mit“. Sarajevski dugi pucnji 1914. Događaj-narativ-pamćenje, prir. Vahidin Preljević, Clemens Ruthner, 53-68. Zenica: Vrijeme, 2015.

- $\quad$ Dedijer, Vladimir. Sarajevo 1914. Beograd: Prosveta, 1969. (cyrillic)

- $\quad$ Dimić, Ljubodrag. Kulturna politika Kraljevine Jugoslavije 1918-1941, knj. I. Beograd: Stubovi kulture, 1996. (cyrillic)

- Hobsbom, Erik. „Uvod: kako se tradicije izmišljaju“. Izmišljanje tradicije, ur. Erik Hobsbom, Terens Rejndžer, 5-25. Beograd: Biblioteka XX vek, 2002.

- Jevtić, Borivoje. „Gavrilo Princip”. Glas naroda 272/1920/2. (cyrillic)

- Ković, Miloš. Gavrilo Princip. Dokumenti i sećanja. Novi Sad: Prometej, Beograd: RTVS, 2014. (cyrillic)

- Kuljić, Todor. Prognani pojmovi. Neoliberalna pojmovna revizija misli o društvu. Beograd: Clio, 2018.

- Masleša, Veselin. Mlada Bosna, Sarajevo: Izdanje Državnog izdavačkog preduzeća Bosne i Hercegovine, 1945. (cyrillic)

- Müller-Funk, Wolfgang. „O znakovitosti datuma 1914. Čitanje Krausa, Musila, Rotha, Andrića i Iwaszkiewicza kroz prizmu Hansa Blumenberga“. Sarajevski dugi pucnji 1914. Događaj-narativ-pamćenje, prir. Vahidin Preljević, Clemens Ruthner, 69-86. Zenica: Vrijeme, 2015.

- $\quad$ Palavestra, Predrag. Književnost Mlade Bosne, I-II. Sarajevo: Svjetlost, 1965.

- $\quad$ Palavestra, Jovan. „U vidovdanskom hramu“. Narodno jedinstvo 29/1920, 1. (cyrillic)

- $\quad$ Palavestra, Jovan. „Gavrilo Princip i drugovi“. Narodno jedinstvo 129/1920, 2-3. (cyrillic)

- $\quad$ Popović, Cvjetko. Sarajevski Vidovdan 1914, Doživljaji i sećanja. Beograd: Prosveta, 1969. (cyrillic)

- Vasin, Goran. „Prečanska politika i sarajevski atentat“. Corovićevi susreti 2013. godine. Međunarodni naučni skup istoričara Sarajevski atentat1914, ur. Vojislav Maksimović, Draga Mastilović, 164-176. Gacko: SPKD „Prosvjeta“, Opštinski odbor Gacko, 2014. (cyrillic)

- Vervaet, Stjin. Centar i periferija u Austro-Ugarskoj. Dinamika izgradnji nacionalnih identiteta u Bosni i Hercegovini od 1878. do 1918. godine na primjeru književnih tekstova. Zagreb-Sarajevo: Synopsis, 2013.

- $\quad$ Bratstvo, list za vjersko i narodno prosvjećivanje, Sarajevo, 1939. (cyrillic)

- Glas naroda, političko-informativni list, organ Demokratske stranke za BiH, Sarajevo 1920. (cyrillic)

- Glas slobode, organ Socijalističke radničke partije Jugoslavije (komunista), 1920. (cyrillic)

- $\quad$ Hrvatska sloga, novine Hrvatske težačke stranke u Bosni i Hercegovini, Sarajevo, 1920.

- $\quad$ Hrvatski dnevnik, za interese bosansko-hercegovačkih Hrvata, 1914.

- Istina, srpski demokratski organ, 1914. (cyrillic) 
- Jugoslovenska pošta, političko-informativni list, Sarajevo, 1930, 1938, 1939.

- Jugoslovenski list, političko-informativni list, Sarajevo, 1930.

- $\quad$ Narod, političko-informativni list, Sarajevo, 1921. (cyrillic)

- $\quad$ Narodno jedinstvo, službeni organ Pokrajinske vlade, Sarajevo, 1920. (cyrillic)

- $\quad$ Pravda, glasilo Jugoslovenske muslimanske organizacije, Sarajevo, 1920.

- $\quad$ Sarajevski list, zvanični list bosanske vlade, 1917.

- $\quad$ Srpska riječ, radikalni list, 1919, 1920,1921. (cyrillic)

- Večernja pošta, političko-informativni list, Sarajevo, 1927, 1929.

- Vukov, Nikolai. „Collective Interments: Ossuaries and Brotherly Mounds in Bulgaria, 1944-1989“. Dying and Death in 18th-21st Century Europe, edited by Marius Rotar, Adriana Teodorescu, Cambridge Scholars Publishing, 2011, 129-149. Datum pristupa 15. januar 2019. https://books.google. ba/books?id=phYrBwAAQBAJ\&pg=PA181\&lpg=PA181\&dq=prenos+kost iju\&source=bl\&ots=Dz_FzL8r4b\&sig=ACfU3U0eX3QI-2IniHBaDz93z53_ iKh76Q\&hl=en\&sa=X\&ved=2ahUKEwjR-06fjPDhAhWwwsQBHfwpCKE4C

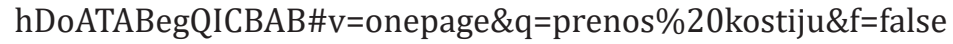




\title{
Summary
}

Sonja Dujmović

\section{How a Revolution Disappeared - The Case of Gavrilo Princip}

\begin{abstract}
This paper aims to answer the question of why the contemporary discussions of the Sarajevo assassination ignore its revolutionary nature. Furthermore, it tries to explain how the assassination and its perpetrator, Gavrilo Princip, became part of the collective memory, how they were reduced to the requirements of the relevant national-religious narratives, redefined, and reimagined accordingly.

KEY Words: Gavrilo Princip, Assassination, Revolution, Condemnation, Ceremonial Funeral, Neutralization, Religious and National Construct, Changed Identity, Interpretations, Political Instrumentalization
\end{abstract}

Serbian dignitaries were the first to distance themselves from the assassination committed by Gavrilo Princip and the heads of the Serbian Orthodox Church stigmatized and excommunicated him. However, shortly after the end of World War I, already in 1920, Princip's remains were returned to his homeland, which marked his and his comrades' symbolic return to their national-religious cradle. At the same time, this meant that the revolutionary nature and potential of the Sarajevo assassination act were neutralized. Sacralization excludes the possibility of reconsideration, and therefore, authorities have claimed their exclusive right to interpret Princip's mythological-religious identity ever since, thereby isolating their interpretation from the historical reality. Changes in Princip's symbolic revolutionary image were further disabled by étatist Yugoslav ideology of the 1930s and by constant reconsiderations of the responsibility for the war. In 1939, when Bosnia and Herzegovina were in political turmoil and the war and disintegration of Yugoslavia felt imminent, Princip and his comrades served as means of strengthening the sense of community once again. Nowadays, the principal revolutionary nature of their act has been politically instrumentalized once more. Princip is being reduced to a para-religious figure and turned into a national-political saint with the aim of fostering further political differences between national and religious groups. More importantly, current political use of Gavrilo Princip disables fruitful dialogue, unity, potential youth organizing, and social unrest, while at the same time highlighting religious, nationalistic, and capitalist values and paradigms, and obscuring social exploitation. 